\title{
Biodegradation of Stored jet Fuel by a Nocardia sp. Isolated from Contaminated Soil
}

\author{
Edelvio de Barros Gomes ${ }^{1}$, Adriana Ururahy Soriano², Rita de Cássia Mendonça de \\ Miranda $^{3}$, Maria de Fátima Vieira de Queiroz Sousa ${ }^{3}$ and Nei Pereira Jr. ${ }^{{ }^{*}}$ \\ ${ }^{1}$ Laboratório de Engenharia Bioquímica; Escola de Química; Universidade Federal do Rio de Janeiro; Centro de \\ Tecnologia Bl "E" Ilha do Fundão; 21949-900; Rio de Janeiro - RJ - Brasil. ${ }^{2}$ Centro de Pesquisas da Petrobras, \\ Av. 1; Quadra 7; Ilha do Fundão; 21949-900; Rio de Janeiro - RJ - Brasil. ${ }^{3}$ Laboratório de processos \\ Fementativos; Departamento de Antibióticos; Universidade Federal de Pernambuco; Campus Universitário s/n \\ 50670-901; Recife - PE - Brasil
}

\begin{abstract}
The aim of this study was to investigate the potential of degradation of an autochthonous bacterial strain, isolated from petroleum derivatives contaminated soil samples against jet fuel hydrocarbons. The autochthonous bacterial strain was characterized as Nocardia sp. Evaluation of their degrading abilities was carried out by presumptive assays as redox indicator test and by observations of surface tension decreases in aqueous medium. Degradation of jet fuel hydrocarbons was evaluated by chromatographic methods. Experiments were performed in flasks at two biostimulation rates. A bacterial strain of Pseudomonas aeruginosa UFPEDA 39 was utilized as a reference microorganism. The bacterial strain, identified as Nocardia $\mathrm{sp}$, demonstrate high ability to degrade jet fuel compounds as well as to produce surface active compounds when compared to the reference microrganism.
\end{abstract}

Key words: biodegradation, Nocardia, jet fuel

\section{INTRODUCTION}

Contamination of soils and aquatic environments by petroleum hydrocarbons as a consequence of accidental spillage can cause serious damages to living organisms. Since the spills implies in economical and environmental losses, authorities and petrochemical industry have been forced to reduce the risk of spillage through the modifications in technical standards and operational procedures (Milne et al, 1998; Oudot et al, 1994). Referred as a cost-effective, natural and efficient clean-up treatment of hazardous waste, bioremediation technologies have been more intensively studied in the last three decades (Atlas, 1995a). Studies on petroleum hydrocarbon biodegradation have focused on biodegradability of crude oil, petroleum derivatives or isolated hydrocarbons.

Microbial action is directly influenced by several biotic and abiotic parameters, amongst these, special attention must be given to temperature, $\mathrm{pH}$, nitrogen and phosphorous sources, as well as microelements (Atlas 1984; Atlas, 1995b; Ruberto et al, 2003).

Petroleum derivatives are a complex mixture of hydrocarbons and their biodegradability depends on their bioavailability, which is directly related to

*Author for correspondence: nei@eq.ufrj.br 
composition, chain length, ramification and steric and electronic effects. As a rule, n-alkanes are more degradable than branched alkanes; polycyclic aromatics hydrocarbons are less degradable than monocyclic aromatics. Jet fuel composition includes, predominantly, n-alkanes and branched-alkanes, ranging from 15 to 30 carbon atoms and few amounts of polycyclic aromatics hydrocarbons (PAH) are also observed in trace levels (Bernabei et al, 2003).

As reported in literature as hydrocarbon-degrading microorganisms, Nocardioforms actinomycetes have been frequently isolated from hydrocarboncontaminated sites. The present work aimed at the characterization of a Nocardia bacterial strain as a jet fuel-degrading microorganism.

\section{MATERIAL AND METHODS}

\section{Jet fuel samples}

The jet fuel samples used in this work were harvested from the tanks of the Suape Terminal, Pernambuco, Brazil, with the consent of the Brazilian Oil Company (Petrobrás SA). Preliminary analysis of total petroleum hydrocarbons (TPH) produced a profile of hydrocarbons varying from $\mathrm{nC}_{9}$ to $\mathrm{nC}_{31}$, with predominance of hydrocarbons ranging from $\mathrm{nC}_{11}$ to $\mathrm{nC}_{17}$. Polycyclic aromatic hydrocarbons were detected in trace levels.

\section{Microorganisms}

The autochthonous bacterial strain was isolated from petroleum derivatives contaminated soil samples, by utilizing pour plate technique. Jet fuel was nebulized onto plate dishes containing Büshnell-Haas solid mineral medium $\left(\mathrm{KH}_{2} \mathrm{PO}_{4}\right.$ $1.0 \mathrm{~g} ; \mathrm{K}_{2} \mathrm{HPO}_{4} 1.0 \mathrm{~g} ; \mathrm{NH}_{4} \mathrm{NO}_{3} 1.0 \mathrm{~g} ; \mathrm{MgSO}_{4} .7 \mathrm{H}_{2} \mathrm{O}$ $0.2 \mathrm{~g} ; \mathrm{FeCl}_{3} 0.05 \mathrm{~g} ; \mathrm{CaCl}_{2} .2 \mathrm{H}_{2} \mathrm{O} 0.02 \mathrm{~g}$; Agar $15.0 \mathrm{~g}$ and $\mathrm{H}_{2} \mathrm{O} 1000 \mathrm{~mL}$ ). Colonies were transferred to the complex medium Tryptic Soy Agar - TSA ${ }^{\mathrm{TM}}$ (Oxoid). The selected culture was identified on the basis of its composition in terms of Fatty Acids Methyl Ester (FAME) profile by gas chromatography using a CG 5890 (HewlettPackard, series II) equipped with a flame ionization detector, employing the microbial identification system (MIDI ${ }^{\mathrm{TM}}$ ).

A known bacterial strain of Pseudomonas aeruginosa DAUFPE 39 from the Department of Antibiotics of the Federal University of
Pernambuco (UFPE), Brazil, was utilized as the alochthonous reference microorganism.

\section{Presumptive assays}

The redox indicator 2,6 dichlorophenol indophenol (DCPIP) was utilized in aqueous phase as an oxidation indicator as indicated by Hanson et al, (1993) and adapted by Miranda et al, (2007). Cultures were allowed to grow in Büshnell-Hass mineral medium (BH) containing $0.02 \mathrm{~mL}$ of DCPIP and $1 \%$ of jet fuel as the sole carbon source, in $250 \mathrm{~mL}$ conical flasks at $30 \pm 1^{\circ} \mathrm{C}$ and 200rpm. Abiotic control was utilized in both experiments. The required time that promote the changes in colour of medium was registered.

Alochthonous and autochthonous cultures were acclimated in $\mathrm{BH}$ modified media by increasing jet fuel concentrations (from 1 to $15 \%$ ) at two C:N ratio (95:1 coded $\mathrm{N} 1$ and 23:1 coded N2), at the same temperature and agitation conditions described previously. Cultures were allowed to grow by 12 days in each jet fuel concentration and, afterwards were re-inoculated in a fresh medium containing a new jet fuel concentration (different from the previous one). Initial inoculum population was ca. $10^{8} \mathrm{CFU} \cdot \mathrm{mL}^{-1}$.

\section{Biodegradation Assays}

After acclimatation period, biodegradation assays were performed in $2,800 \mathrm{~mL}$ conical flasks, containing $100 \mathrm{~mL}$ aliquot of inoculum from the previuous acclimated culture in the series of acclimatation experiments, corresponding to approximately $17 \% \quad(\mathrm{v} / \mathrm{v}) ; 380$ milliliters of modified $\mathrm{BH}$ media, corresponding to $68 \%(\mathrm{v} / \mathrm{v})$ and $80 \mathrm{~mL}$ of jet fuel, corresponding to $14 \%(\mathrm{v} / \mathrm{v})$ of total volume. Modified BH media were adjusted at two C:N ratios: $95: 1$ and $23: 1$, by adding ammonium nitrate to the media. The approximated carbon mass was calculated considering the range of hydrocarbons in the jet fuel. The majority of hydrocarbons in the jet fuel samples were straight-chain $(\cong 92.15 \%)$ and branched-alkanes $(\cong 7.8 \%)$. Since the general formula of these compounds is $\mathrm{C}_{n} \mathrm{H}_{2 n+2}$, the pondered average of carbon in the samples was 0.8495 , and the approximated carbon mass was given as: $m C=\rho v f$, were, $m C$ was the approximated carbon mass; $\rho$ was the jet fuel density; $v$ was the jet fuel volume and $f$ was the factor considered as the average of all Ccompounds ranges proportion (0.8495). 
Ammonium nitrate mass was adjusted to compose the desired $\mathrm{C}: \mathrm{N}$ ratio as follows:

$m \mathrm{NH}_{4} \mathrm{NO}_{3}=\frac{(\mathrm{mC} / \mathrm{mCd}) \times 80,05}{28}$, where, $\mathrm{mNH}_{4} \mathrm{NO}_{3}$

was the ammonium nitrate utilized mass to compose the $\mathrm{C}: \mathrm{N}$ ratio; $m C$ was the approximated carbon mass; $m C d$ was the carbon desired proportion to compose the $\mathrm{C}: \mathrm{N}$ ratio. The calculated $\mathrm{NH}_{4}\left(\mathrm{NO}_{3}\right)$ mass to $95: 1 \mathrm{C}: \mathrm{N}$ ratio, was $1.71 \mathrm{~g}$, and to the $23: 1 \mathrm{C}: \mathrm{N}$ ratio, was $6.99 \mathrm{~g}$.

During biodegradation experiments, $\mathrm{pH}$, surface tension and microbial growth were measured at five-day intervals. Surface tension was measured in an analogical tensiometer (DüNoy ${ }^{\mathrm{TM}}$ ), as recommended by ASTM (1999); pH was measured in a digital $\mathrm{pH}$-meter and microbial growth was quantified by counting Colonies Forming Unities (CFU) in plates containing $\mathrm{TSA}^{\mathrm{TM}}$ medium. Samples of $1 \mathrm{~mL}$ were withdrawn from biodegradation conical flasks and serially diluted from $10^{-1}$ to $10^{-6}$. Thereafter, $0.1 \mathrm{~mL}$ of an appropriate dilution was spread onto the medium surface (spread plate technique) and incubated by $24 \mathrm{~h}$. Biodegradation assays, microbial growth and all analytical measurements were made in triplicate.

Reduction on jet fuel (most significantly hydrocarbons) was estimated by means of comparing the peaks of abiotic control to those of the treated samples, and results were reported in terms of percentage of reduction of hydrocarbons. Samples were centrifuged at $10,000 \mathrm{rpm}$ at $5^{\circ} \mathrm{C}$, followed by heptane extraction. Chromatographic and mass-spectrometric analyses were performed by Gas Chromatograph coupled to the mass spectrometer (Shimadzu ${ }^{\mathrm{TM}}$, GC-MS Model: 17A/QP5050) utilizing a 30m x $0.35 \mu \mathrm{m} \times 0.25 \mu \mathrm{m}$ chromatographic column DB-5 (5\% diphenyl and 95\% dimethylpolysiloxane). Oven temperature was programmed from 60 to $280^{\circ} \mathrm{C}$ at $10^{\circ} \mathrm{C} \cdot \mathrm{min}^{-1}$, and held for $35 \mathrm{~min}$. Helium was utilized as the carrier gas. The Thermal Conductivity Detector's (TCD) temperature was adjusted to $280^{\circ} \mathrm{C}$. Areas of the most significantly peaks of chromatograms were automatically calculated and peaks were integrated considering the height. Individual compounds were identified by mass spectrometry utilizing electron impact ionization system (EI).

\section{RESULTS AND DISCUSSION}

\section{Selected culture}

High $\mathrm{pH}$ and surface tension reduction were observed to the autochthonous culture of Nocardia $s p$, when compared to those reported by Neufeld et al (1980), who have worked with other species of actinomycetes.

As reported by Ron and Rosemberg (2001), biosurfactants allowed the uptake and utilization of hydrocarbons, leading to an increase in microbial growth and a decreasing in surface tension and $\mathrm{pH}$ in aqueous media. Surface tension and $\mathrm{pH}$ are indirect parameters to investigate the biodegradability of hydrocarbons. Reduction in surface tension and $\mathrm{pH}$ observed to the cultures indicated the presence of biosurfactants and production of acid metabolites as an evidence of biodegradation occurrence. Evaluations of these parameters associated to the DCPIP screening technique are important tools in the investigation of degrading capabilities of microorganisms.

\section{Biodegradation}

Nine most significantly compounds were selected based on their chromatographic peaks. Mass spectrometric analysis identified the straight-chain alkanes: n-decane, n-undecane, n-dodecane, ntridecane, and the branched alkanes: 4metildecane, 3-etil 2,7-dimetiloctane, 6metildodecane, 2,6,10,14-tetrametilheptadecane, 2,6,11-trimetildodecane (Table 1).

Alochthonous culture eliminated the straight-chain alkane n-decane and the branched-alkanes 4metildecane and 3-etil 2,7-dimetiloctane, after 60 days in the 23:1 C:N ratio (Table 1). Several reports have showed that straight-chain alkanes have often been found to be readily degraded in field and laboratory studies, by a large diversity of bacteria (De Jong et al, 1997). The most evidenced mechanism to describe the straight-chain alkanes biodegradation is the terminal oxidation which leads to the conversion of hydrocarbons into the corresponding more stable compounds, following the sequence of oxidation of the terminal carbon, from the more reduced to the more oxidized compound, such as alcohols, aldehydes, carboxylic acids and fat acids (Alexander, 1994; Atlas 1984; Glazer and Nikaido, 1995; Seeger et al, 1997). Although it is generally true that branched alkanes are more recalcitrant than their equivalent straight- 
chain alkanes, studies have demonstrated that many of these branched compounds were more degradable than they have previously been reported (Geerdink et al, 1996). Present results showed that this occurrence was shown by autochthonous culture.

Table 1 - Degradation in jet fuel hydrocarbons after 60-day process by pure and mixed cultures in both 95:1 and 23:1 C: N ratio.

\begin{tabular}{|c|c|c|c|c|}
\hline $\mathrm{C}: \mathrm{N}$ ratio & Hydrocarbon & & Degradation & \\
\hline \multirow[t]{10}{*}{ 95:1 } & & Sterile control & Nocardia $s p$ & DAUFPE 39 \\
\hline & n-decane & 0 & 93,80 & 98,60 \\
\hline & 4-metildecane & 0 & 92,00 & 98,40 \\
\hline & 3-etil-2,7-dimetiloctane & 0 & 88,90 & 99,10 \\
\hline & n-undecane & 0 & 99,50 & 96,40 \\
\hline & Dodecane & 0 & 97,00 & 88,60 \\
\hline & 6-metil-dodecane & 0 & 96,30 & 92,40 \\
\hline & 2,6,10,14-tetrametilheptadecane & 0 & 84,60 & 97,00 \\
\hline & n-tridecane & 0 & 94,30 & 87,20 \\
\hline & 2,6,11-trimetildodecane & 0 & 80,80 & 88,60 \\
\hline \multirow[t]{10}{*}{ 23:1 } & & Sterile control & Nocardia sp & DAUFPE 39 \\
\hline & n-decane & 0 & 100 & 99,00 \\
\hline & 4-metildecane & 0 & 100 & 99,90 \\
\hline & 3-etil-2,7-dimetiloctane & 0 & 100 & 99,99 \\
\hline & n-undecane & 0 & 99,60 & 99,10 \\
\hline & Dodecane & 0 & 99,80 & 97,20 \\
\hline & 6-metil-dodecane & 0 & 99,99 & 99,40 \\
\hline & 2,6,10,14-tetrametilheptadecane & 0 & 99,90 & 98,20 \\
\hline & n-tridecane & 0 & 99,80 & 96,30 \\
\hline & 2,6,11-trimetildodecane & 0 & 99,80 & 97,90 \\
\hline
\end{tabular}

Branched alkanes, such as 2,6,10,14tetrametilheptadecane and 2,6,11 trimetildodecane, were the most recalcitrant compounds (Table 1). This low biodegradability could be associated to the structure of these compounds. Generally, all kinds of bacteria oxidize compounds with a lower molecular mass more easily. Amongst the hydrocarbons, aliphatic compounds are likely to be more easily degraded. Also, between branched and straight-chain alkanes, bacteria preferentially degrade straight-chain alkanes hydrocarbons. Bacteria will utilize compounds that are more difficult to degrade only if they are exposed previously to such compounds to allow the development of an adapted population. The autochthonous pure culture presented highest reduction in all the investigated compounds either with 95:1 and 23:1 C:N ratios. The 23:1 C:N ratio promoted higher biodegradation efficiency than 95:1 for both autochthonous and alochthonous cultures (Table 1). The influence of carbonnitrogen ratio (C:N) and carbon-nitrogenphosphorous ratio $(\mathrm{C}: \mathrm{N}: \mathrm{P})$ on biodegradation has been well reported (Walworth et al 1997). Decreases in hydrocarbon concentration are expected when nitrogen supply is augmented.

The alochthonous bacterial strain Pseudomonas aeruginosa DAUFPE 39 demonstrated high adaptation to the carbon source, which could be confirmed by the microbial growth curve (Fig. 1a), and the percentage of remaining hydrocarbons (as summarized in Table 1). Owing to acclimatation period, using increasing concentrations of jet fuel, the lag phase was diminished (Fig. 1b). High surface tension and $\mathrm{pH}$ reduction were observed for autochthonous culture (50.7 and 30.4\%, respectively) as showed in Table 2 . These results confirmed the production of biosurfactants by the degrading bacteria. In general, bacteria growing in hydrocarbon environments produce biosurfactants 
although some bacteria are not capable to produce these molecules, and others are capable to reduce the surface tension by means of cell surface hydrophobicity, acting the cell itself as a biosurfactant. This feature depends on the mechanism of assimilation of hydrocarbons utilized by each bacterial group (Alexander, 1994; Ron and Rosemberg, 2001). (a)

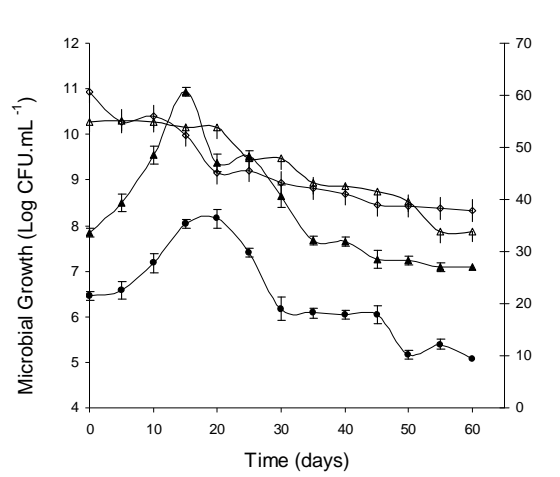

(b)

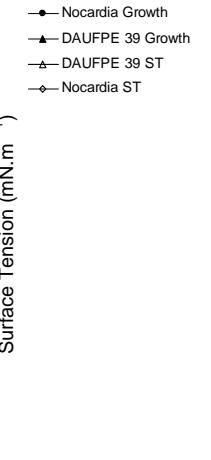

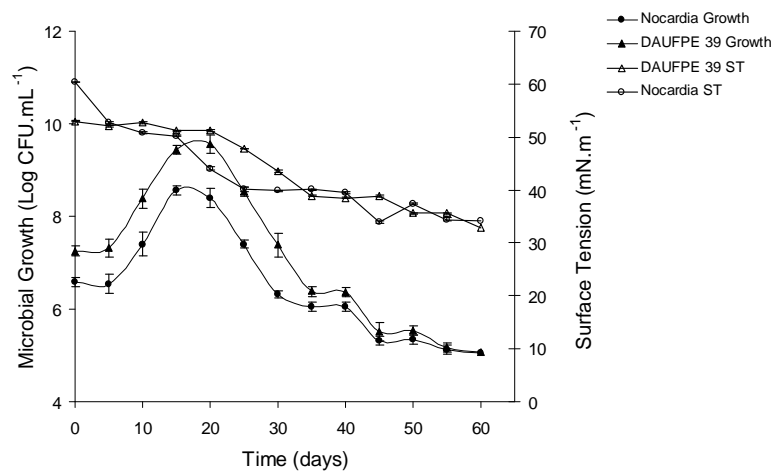

Figure 1 - Microbial growth and surface tension (ST) of Nocardia sp and Pseudomonas aeruginosa (DAUPE 39) - (a) 95:1 C:N ratio (b) 23:1 C:N ratio.

Table 2 - Surface tension and $\mathrm{pH}$ reduction percentage of aqueous media after 60 days by cultures in both 95:1 and 23:1 C:N ratio.

\begin{tabular}{lcccc}
\hline Culture & \multicolumn{2}{c}{ pH reduction $(\boldsymbol{\%})$} & \multicolumn{2}{c}{ Surface tension reduction $(\%)$} \\
\hline & $95: 1$ & $23: 1$ & $95: 1$ & $23: 1$ \\
Nocardia $s p$ & 31.4 & 30.4 & 51.7 & 50.7 \\
DAUFPE 39 & 26.8 & 21.3 & 40.0 & 37.9 \\
\hline
\end{tabular}

\section{CONCLUSIONS}

The studied bacterial strain of Nocardia sp demonstrated high abilities to degrade the analyzed constituents of jet fuel. No significant difference were observed between the $\mathrm{C}: \mathrm{N}$ ratios and further investigations must be conduced towards the optimization of this parameter. Pseudomonas aeruginosa DAUFPE 39 demonstrate high adaptation to the carbon source, as shown by the cell growth and reduction of the surface tension.

\section{ACKNOWLEDGEMENTS}

Authors would like to thank CNPq, FINEP/CTPetro for financial support during this research.

\section{RESUMO}

O presente estudo objetivou a investigação da capacidade degradadora de uma linhagem bacteriana autóctone (isolada de amostras de solo contaminadas com derivados de petróleo) contra hidrocarbonetos de querosene de aviação. A linhagem foi caracterizada como Nocardia sp. A avaliação do seu potencial degradador deu-se realizada mediante testes com indicador redox e observações na redução da tensão superficial na fase aquosa. A degradação do querosene foi avaliada por métodos cromatográficos. Os experimentos foram realizados utilizando-se duas taxas de bioestímulo. Uma linhagem bacteriana Pseudomonas aeruginosa UFPEDA 39 foi utilizada como referência. A linhagem autóctone demonstrou alta eficiência na degradação de hidrocarbonetos do querosene bem como para produzir compostos ativos de superfície quando comparada com a linhagem de referência. 


\section{REFERENCES}

Alexander, M.: (1994), Biodegradation and Bioremediation. academic Press, 2ed.

ASTM D - 971. 99 ${ }^{\text {th }}$, Standard tests Method for Interfacial Tension of Oil against Water by the Ring in: Method - American Society for testing and Materials, 1999.

Atlas, R. M., 1984. Petroleum Microbiology. New York. Macmillan Publishing Company.

Atlas, R. M., (1995a), Bioremediation of Petroleum Pollutants. International Biodeterioration and Biodegradation. pp 317- 327.

Atlas, R. M., (1995b), Handbook of Media for Environmental Microbiology. London. CRC Press.

Bernabei, M.; Reda, R.; Galiero, R.; Bocchinfuso, G., 2003. Determination of total and polycyclic aromatic hydrocarbons in aviation jet fuels. Journal of Chromatography A, 985, 197-203.

De Jonge, H., Freijer, J.I., Verstraten, J.M., Westerveld, J., Van Der Wielen, F.W.M., (1997), Relation between bioavailability and fuel oil hydrocarbon composition in contaminated soils. Environmental Science and Technology, 31, 771 \pm 775 .

Geerdink, M.J., Kleijntjens, R.H., van Loosdrecht, M.C.M., Luyben,K.C.A.M., (1996), Microbial decontamination of polluted soil in aslurry process. Journal of Environmental Engineering, 11, 975 9982.

Glazer, A. N.; Nikaido, H., (1995), Microbial Biotechnology - Fundamentals of Applied Microbiology. New York. W. H. Freeman and Company Editors.

Hanson, K. G.; Desai, D.; Desai, A. J., (1993), A rapid and simple screening technique for potential crude oil degrading microorganisms. Biotechnology Techniques 7, 745-748.
Neufeld, R. J.; Zajic, J. E.; Gerson, D. F., (1980), Cell surface Measurements in Hydrocarbon and Carbohydrate Fermentetions. Applied and Environmental Microbiology. 39. 511-517.

Milne, B.J.; Baheri, H.R.; Hill, G. A., (1998), Composting of a heavy oil refinery sludge. Environmental Progress, 17, 24-27.

Miranda, R.C.M; Souza, C.S.; Gomes, E.B.; Lovaglio, R.B.; Lopes, C.E.; Sousa, M. F. V. Q., (2007), Biodegradation of Diesel Oil by Yeasts Isolated from the Vicinity of Suape Port in the State of Pernambuco - Brazil. Brazilian Archives of Biology and Technology. 50 (1), 147-152.

Oudot, J., (1994), Soil pollution by petroleum products and treatments. Analysis Magazine, 22, 16 - 18.

Ron, E. Z.; Rosenberg, E., (2001), Natural roles of biosurfactants. Environmental Microbiology 3, 229236.

Ruberto, L.; Vasquez, S., C.; Cormack, W. P. M. (2003), Effectiveness of the Natural Bacterial flora, Bioestimulation and Bioaugmentation on the Bioremediation of Hydrocarbon Contaminated Antarctic Soil. Internat. Biodeteriorat. and Biodegradat., 52, 115-125

Seeger, M.; Timmis, K., N.; Hofer, B., (1997), Bacterial Pathways for the Degradation of Polychlorinated Biphenyls. Marine chemistry 58, 327-33.

Walworth, J. L.; Woolard, C. R.; Braddock, J. F.; Reynolds,C. M., (1997), The Role of Soil Nitrogen Concentration in Bioremediation. Fourth International in situ and On-site Bioremediation Symposium, New Orleans, April 28 May 1, Battelle. Bioremediation, 9, 283-288
Received: September 24, 2007; Revised: May 08, 2008; Accepted: January19, 2009. 